PRIMANOMICS : JURNAL EKONOMI DAN BISNIS - VOL. 19 NO. 1 (2021)

Versi Online Tersedia di : https://jurnal.ubd.ac.id/index.php/ds

| 1412-632X (Cetak) | 2614-6789 (Online) |

\title{
Comparative Analysis of Increasing Online Purchase Decisions during the Covid-19 Pandemic Period among Tangerang area and South Tangerang
}

\author{
Diana Silaswara $\left.{ }^{1}\right)$ \\ diana.silaswara@ubd.ac.id \\ Andy ${ }^{2}$ \\ andy.andy@ubd.ac.id \\ Tjong Se Fung ${ }^{3)}$ \\ Tjong.sefung@ubd.ac.id
}

1) 2) 3)Universitas Buddhi Dharma Tangerang, Indonesia, Banten

\begin{abstract}
The basis of research aims to determine the impact of the Covid-19 pandemic, especially on the factors that trigger online purchase decisions made. This study is a comparative study because it compares the effect of Online Promotion (X1) and Lifestyle (X2) Online Purchasing Decisions $(Y)$ between the areas of Tangerang City and South Tangerang.

The research questionnaire was distributed within 11 days and obtained 165 valid respondents. The questionnaire was processed using the SPSS 20 program, and from the validity test results it turns out that only 38 statements are valid. From other test results, it was found that the statement was constant, normally distributed and did not occure heteroscedastidity and multicollinearity in the two regression equations formed in each region. The relationship between variables in each region is not very strong.

The results obtained are that all hypotheses are proven, namely: Online Promotion and Lifestyle Influence on Purchasing Decisions, as well as proven that there are differences in influencing factors in the two regions. The difference that occurs is in Tangerang City the dominant purchasing decision is influenced by the Online Promotion offered, while in South Tangerang the two factors affect equally.
\end{abstract}

Keywords: Online Promotion, Lifestyle, Online Purchasing Decisions 


\section{PRELIMINARY}

\section{A. Background}

The current Covid-19 pandemic has changed the world economy, including in Indonesia. Since it was detected that a member of the community was positively infected with Covid-19 on March 2, 2020, many people's habits have changed, both from the social side of the community and fulfillment of daily needs. Based on the results of observations made by the government regarding the economy, in suppressing the spread of Covid-19, new provisions lead to changes in the lifestyle of people who usually buy goods offline, so almost all the necessities as much as possible are purchased online. Changes in transaction patterns from offline to digital, the high level of public consumerism is also supported by promotions provided by the marketplace, online motorcycle taxi applications (gojek and grab) as well as other e-wallet applications in the form of discount promotions or delivery. Based on the above background, the writer intends to examine which factors are more dominant in influencing current consumer purchasing decisions between lifestyle changes or promotion offered by e-commerce.

\section{A. Problem Identification}

1. The Covid 19 pandemic has just started to enter Indonesia on 02 March 2020.

2. The government has issued many policies intended to prevent the spread of the Covid-19 pandemic from becoming more widespread.

3. There was an increase in e-commerce transactions that occurred during the Covid-19 pandemic.

4. There were changes in transaction patterns and consumer lifestyles during the Covid-19 pandemic.

5. Due to changes in shopping patterns from offline to online, all e-commerce companies are competing to offer a number of promotional programs to attract public shopping interest.

\section{B. Problem Formulation}

1. How big is the influence of online promotion and lifestyle online purchasing decisions consumers in the city of Tangerang?

2. How big is the influence of online promotion and lifestyle online purchasing decisions for consumers in the city of South Tangerang?

3. Are there characteristic differences in purchasing decision making between consumers in Tangerang City and consumers in SouthTangerang?

\section{B. Research purposes}


1. To determine the magnitude of the influence online promotion and lifestyle online purchasing decisions among consumers in the city of Tangerang.

2. To determine the magnitude of the influence of online promotion and lifestyle online purchasing decisions for consumers in the city of South Tangerang.

3. To find out the differences in character in making purchasing decisions between consumers from the Tangerang City area and consumers from the South Tangerang area, it is seen from Online Promotion and Lifestyle.

\section{THEORETICAL REVIEW}

\section{A. PREVIOUS RESEARCH}

\section{Grifan Agus Prastowo (2018)}

The research conducted by (G. A. Prastowo, 2018) is entitled Online Promotion of Purchasing Decisions at PT Mitra Pariwara Gramed Malang. The results of this study prove that the application of online promotion by companies has a positive effect in influencing purchasing decision making, although the promotion variable only affects $19 \%$ of changes in consumer purchasing decisions.

\section{Suci Dwi Pangestu, Sri Suryoko. (2016)}

This research (Suci Dwi Pangestu, 2016) entitled The Influence of Lifestyle and Prices on Purchasing Decisions (Case Study of Peacockoffie Semarang Customers) was carried out because of the policy of increasing prices in 2014 which resulted in a decrease in customers during the proliferation of coffee shops in the city. Semarang. And the results of this study indicate that the two variables (lifestyle and price) only affect $19.6 \%$ of consumer purchasing decisions.

\section{Agus K., Andy Andy, Eso H., Diana S., T. Sefung (2020)}

(Kusnawan, 2020) made a study entitled The Effect of Digital Payment to Millennial Consumer Purchase Decision which aims to determine the effect of the ease of use of the digital transaction system on the formation of purchasing decisions, and obtained the result that the ease of use of the digital payment system only had an effect of $10.7 \%$ of purchase decisions made by consumers

\section{B. STUDY OF THEORY}

\section{The Covid-19 Virus Pandemic}

This virus was first reported to WHO as the Wuhan Corona Virus (2019-nCov) by the People's Republic of China (PRC) on December 31, 2019 and entered Indonesia on March 02, 2020. Corona Virus Diseases 2019 (Covid-19) is a disease caused by severe acute 
respiratory syndrome coronavirus 2 (SARS-CoV-2), transmitted through direct contact with sufferers through droplets of fluids released by patients.

The government on March 13, 2020 formed a Task Force for the Acceleration of Handling Covid-19, and then the President determined that Covid-19 was a National Disaster. With good handling and on June 1, 2020, the government implemented a 'New Normal', namely steps or efforts made to increase the productivity of the community which had stopped some time ago and caused a decline in activities in people's lives.

\section{Purchase Decisions}

\section{a. Definition}

Purchasing decisions according to Schiffman and Kanuk (2007: 485) in their journal (Suci Dwi Pangestu, 2016) is defined as choosing an action from two or more alternative options. A consumer who wants to make a choice must have an alternative choice.

\section{b. Steps for Making Consumer Decisions}

The steps for making consumer decisions according to Kotler and Keller (2007) in the book Ujang S (2017: 361), namely: (1) recognition of needs, (2) evaluation of alternatives, (3) process of evaluating product and brand choices, (4) purchasing process, and (5) postconsumption evaluation.

\section{c. Purchasing Decision Dimensions and Indicators}

According to Kotler (2007: 222) in his journal (Sudarsono, 2019) states that there are 5 indicators of purchase decisions, including:

(1) The purpose of buying products (2) Information processing to brand selection (3) Product stability (4) Recommendations to others and (5) Making subsequent purchases.

\section{Online Promotion}

\section{a. Online Promotion}

Zainul and Kadarisman in (G. A. Prastowo, 2018) stated that Online Promotion is a process of activities carried out by the company in offering products or services that are introduced or advertised through online media (internet), so there is no face-to-face between buyers and sellers.

\section{b. Purpose and Benefits of Online Promotion}

Strauss and Frost (2012) in Riyanto (2019) state that online promotion has several objectives, including: (1) expand reach at low cost, (2) consumers can track customer comments and response data to marketing activities, (3) create new market shares globally, 
PRIMANOMICS : JURNAL EKONOMI DAN BISNIS - VOL. 19 NO. 1 (2021)

Versi Online Tersedia di : https://jurnal.ubd.ac.id/index.php/ds

| 1412-632X (Cetak) | 2614-6789 (Online) |

(4) make corporate promotion strategies more attractive, (5) make it easier for consumers in making purchases, (6) facilitating a personal approach to customers and potential customers, (7) One to one marketing or delivering products to consumers according to the wishes and needs of each consumer and (8) Twenty hour marketing is an unlimited sales strategy by time.

Quoting from Rebecca's article on the website www.progresstech.co.id the benefits of online promotion of a product include: (1) Convenience, (2) Broader Promotion Range, (3) Efficient Promotion Costs, (4) Unlimited Freedom, (5) Building Relationships and (6) Utilizing Social Media

\section{c. Online Promotion Dimensions and Indicators}

There are dimensions that become a feature of the promotional variables which are used as things that make up the promotional variables. Pribadi (2010:9) quoted by (L. Prastowo, 2016) states that online promotion indicators, among others: (1) attracting attention, (2) attracting interest, (3) attracting desire, (4) attracting action, and (5) Provide a good cover.

\section{Life Style}

\section{a. Definition}

According to Nugroho J Setiadi (2015: 80), a lifestyle is broadly a way of life for a person to spend their time (activity), what they consider important (interest), and what they think about themselves and their surroundings. (Opinion)

\section{b. Type of Lifestyle}

According to Mowen and Minor in Ujang Sumarwan (2011: 45) quoted by Muchlisin Riadi (2018), he states that there are nine types of lifestyle, including: (1) Funcionalist, spend money on important things, (2) Nurturers, young and low-income, (3) Aspirers, focus on enjoying a high lifestyle by spending above-average amounts of money on status goods, particularly housing, (4) Experientials, spend above average amounts on entertainment, hobbies and pleasures (convenience), (5) Succeeders, well-established household, (6) Moral Majority, large expenditures on educational organizations, political matters and houses of worship, (7) The Golden Years, mostly retirees, but their income is the third and highest (8) Sustainer, group of adults, oldest and retired.

\section{c. Factors Affecting Lifestyle}

According to Armstrong in Nugraheni (2003: 15) in an article by Muchlisin Riadi (2018) also states that Lifestyle is influenced by: (1) Attitude, (2) Experience and Observation, (3) Personality, (4) Self-Concept, and (5) Motive.

\section{d. Lifestyle Dimensions and Indicators}


According to Mendey (2009: 93) in Muchlisin Riadi (2018) states that there are three indicators of a person's lifestyle, namely: (1) activity, things done and products consumed by consumers. (2) Interest, is what consumers find attractive to spend time and money on. (3) Opinion represents the views and feelings of consumers in response to global issues. ( Local, economic and social morals).

\section{RESEARCH METHODS}

\section{A. Framework}

\section{Research Model}

This study was conducted to examine the magnitude of lifestyle changes and online promotions offered in influencing the level of online purchasing decisions taken by consumers during the Covid-19 pandemic.

H3

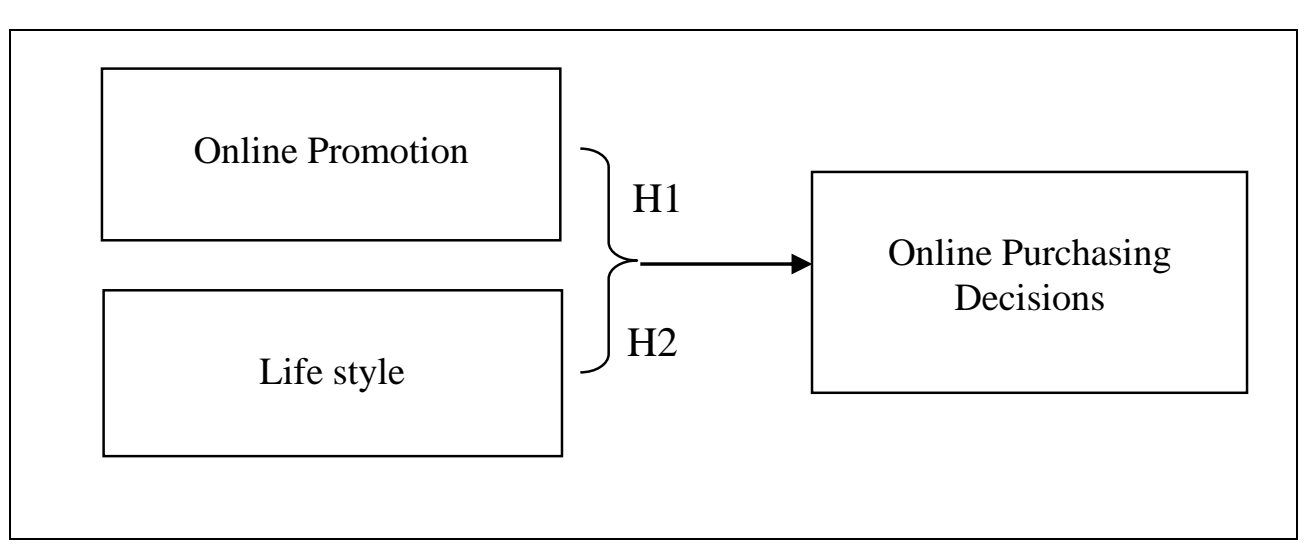

\section{Research Workflow}

In conducting this research, Causal Research steps were carried out based on Anwar Sanusi (2011, page 14) in (Kusnawan et al., 2019). The steps are as follows: (1) Determining research problems, (2) Formulating research objectives (3) Reviewing theories and results of previous research, (4) Formulating research hypotheses, (5) Determining the appropriate population, sample size and sampling method (6) Classifying and defining (conceptually and operationally) research variables, (7) Arranging research instruments, (8) Determining data collection methods, (9) Testing hypotheses and (9) Drawing conclusions based on the results of analysis on hypothesis testing, as well as verifying background theory research.

\section{A. Research Design}

Anwar Sanusi (2011, pp. 13-15) quoted in (Kusnawan et al., 2019) also states that this research has 3 (three) characteristics, including: Descriptive, Causality and Correlational. 
PRIMANOMICS : JURNAL EKONOMI DAN BISNIS - VOL. 19 NO. 1 (2021)

Versi Online Tersedia di : https://jurnal.ubd.ac.id/index.php/ds

| 1412-632X (Cetak) | 2614-6789 (Online) |

1. Purchase Decision $(\mathbf{Y}) \rightarrow$ stage of the consumer's decision-making process to buy a.

2. Online Promotion (X1) $\rightarrow$ efforts to offer products or services to consumers online with the aim of attracting potential customers to buy or consume them.

3. Life Style $\left(\mathbf{X}_{2}\right) \rightarrow$ a description of the behavior, patterns and ways of life shown by a person, their interests and interests and what they think.

The characteristics used include: (1) Domicile (Tangerang City, South Tangerang and etc 1),

(2) Gender (Male Female), (3) Level Education (based on a qualification or official graduation mark), (4) Income Level (average rupiah funds obtained by respondents every month), dan (5) Expenditure Rate (average rupiah funds spent on online shopping by respondents every month)

\section{B. Types, Sources, and Data Collection}

\section{Types and Sources of Data}

Types and sources of data in this research are categorized into: (1) Primary data, data obtained directly, namely questionnaires and (2) Secondary data, data that has been collected by other parties or indirect data.

\section{Population and Sample}

a) POPULATION $\rightarrow$ All residents of Tangerang City and South Tangerang who have made online purchases

b) SAMPLE $\rightarrow$ Valid respondents are respondents who live in region 1 (Tangerang City) and region 2 (South Tangerang) and fill out the questionnaire during the questionnaire distribution.

Due to the exact number of the population is not known and the time limitation of the study, the sample size was determined based on the number of valid respondents who entered when the questionnaire was distributed. And based on the measurement theory of Gay and Diehl (1996) in Anwar Sanusi's book (2012: 100-101) in his journal (Kusnawan et al., 2019), it is stated that research to test the relationship between one or more variables (correlational research), and then the minimum number of samples that must be taken is 30 samples.

\section{Data Collection Techniques}

Secondary data collection was carried out from May to September 2020, while to obtain primary data, the authors used a survey method by distributing questionnaires on September 14-24, 2020.

\section{B. Analysis Method}

Because this research is a qualitative study, so that measurements can be made, the statement 
questionnaire must be changed to quantitative: (1) Because this research is qualitative in nature, the data obtained must first be converted into quantitative research using a Likert scale as a measurement scale and dividing the answer into 5 value categories, namely: Strongly Agree $=5$, Agree $=4$, Neutral $=3$, Disagree $=2$, Strongly Disagree $=1$. The use of the Likert Scale is due to the fact that the questionnaire is closed where the answer choices have been predetermined by researchers. (2) To find out how strong the relationship between $\mathrm{X}$ and $\mathrm{Y}$ is used Pearson Correlation using SPSS 20. (4) To determine the magnitude of the influence of $\mathrm{X}$ on $\mathrm{Y}$, the multiple linear regression analysis tool is used with $\mathrm{t}$ and $\mathrm{F}$ table statistical tests with a tolerance value $\alpha=5 \%$. The model used is: $\mathrm{Y}=\mathrm{a}+\mathrm{b} \mathrm{X} 1+\mathrm{c} X 2+\varepsilon$

\section{F. Research Hypothesis}

$\mathrm{H}_{1}$ : Online Promotion and Lifestyle influence on Purchasing Decision Making for respondents in Tangerang City

$\mathrm{H}_{2}$ : Online Promotion and Lifestyle influence on Purchasing Decision Making for respondents in South Tangerang

$\mathrm{H}_{3}$ : There is a difference between the choice of the influence of Online Promotion and Lifestyle on Purchasing Decisions in the two areas studied.

\section{DATA ANALYSIS}

\section{A. Identification of Respondents}

The distributed questionnaire succeeded in obtaining 213 respondents with 165 valid respondents. Several factors caused the respondent to become invalid, including: (1) Respondent's domicile is outside the City of Tangerang and South Tangerang and (2) The questionnaire was not filled in completely.

And because this study aims to compare the effect of online promotion and lifestyle on purchasing decisions between the cities of Tangerang and South Tangerang, the identity of the respondents is divided into the identities of regional respondents.

Figure Respondent Identity for Tangerang City and South Tangerang

\begin{tabular}{|l|l|c|c|}
\hline \multicolumn{2}{|c|}{ Group } & Tangerang City & South Tangerang \\
\hline \multirow{3}{*}{ Gender } & Male & 63 & 41 \\
\cline { 2 - 4 } & Female & 42 & 19 \\
\hline \multirow{4}{*}{$\begin{array}{l}\text { Level } \\
\text { of education }\end{array}$} & Under Senior High School & 3 & 1 \\
\cline { 2 - 4 } & Senior High School & 46 & 6 \\
\cline { 2 - 4 } & Associate degree & 9 & 6 \\
\cline { 2 - 4 } & Bachelor degree & 34 & 34 \\
\hline
\end{tabular}


PRIMANOMICS : JURNAL EKONOMI DAN BISNIS - VOL. 19 NO. 1 (2021)

Versi Online Tersedia di : https://jurnal.ubd.ac.id/index.php/ds

| 1412-632X (Cetak) | 2614-6789 (Online) |

\begin{tabular}{|c|c|c|c|}
\hline & Magister & 13 & 12 \\
\hline & Above Magister & 0 & 1 \\
\hline \multirow{4}{*}{$\begin{array}{l}\text { Income Level } \\
\text { (IDR) }\end{array}$} & Under 1 Million & 25 & 3 \\
\hline & $1-3$ million & 26 & 2 \\
\hline & $3,000,001$ - 5 million & 31 & 8 \\
\hline & Above 5 million & 23 & 47 \\
\hline \multirow{4}{*}{$\begin{array}{l}\text { Expenditure } \\
\text { Rate (IDR) }\end{array}$} & Under 1 Million & 84 & 32 \\
\hline & 1 - 3 Juta & 18 & 22 \\
\hline & $3,000,001$ - 5 million & 1 & 4 \\
\hline & Above 5 million & 2 & 2 \\
\hline
\end{tabular}

Source: Results of the Questionnaire

\section{A. Classic Assumption Test}

1. Validity, the test was carried out with SPSS 20 and the results of Pearson correlation analysis at $\mathrm{N}=30$ and $\alpha=5 \%$ stated that only 38 questions were valid out of 45 questions.

2. Reliabilitas, the reliability test carried out had a result value of 0.894 or a CONSISTENT statement because according to Sekaran (1992) in Duwi Prayitno's SPSS book (2018: 28) it was stated that the reliability value above 0.8 was GOOD.

3. Data Normality Test, The data normality test is carried out to ensure that the data used is assumed to be feasible to become a sample of the population being studied. A data distribution is considered normal if the results of the Normality Probability Plot output show that the data points are scattered around the line and follow the diagonal direction of the line. And from the results of SPSS it is known that the data on X1, X2 and Y are declared normal because the data points are scattered around the line.
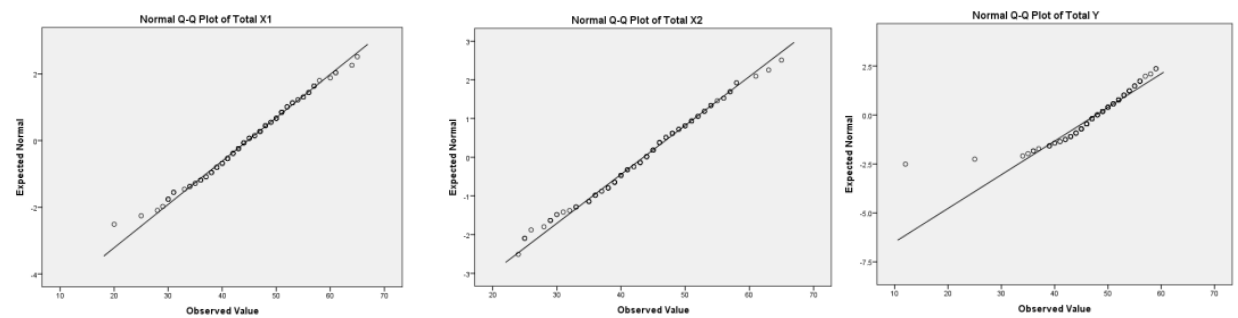

Figure Normality of Variable Data X1, X2 and Y

(Source: Results of the Questionnaire)

\section{Heteroscedasticity Test}

The heterocedasticity test is used to determine in the regression model there is an inequality of variations from the residual value from one observation to another, and the results above can be seen that there is no HETEROCEDASTICITY, because: (1) the points spread above and below zero, (2) The point spread does not form a wavy pattern and (3) the point spread is not patterned 


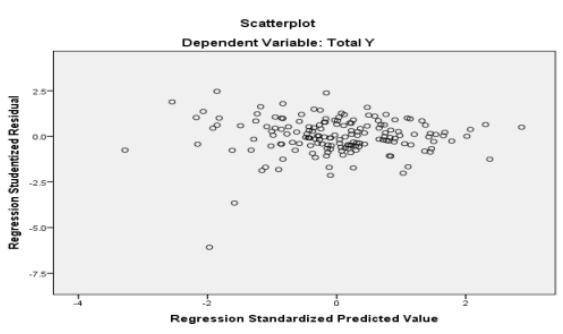

Figure Heteroscedasticity Test

(Source: Results by Questionnaire)

\section{Multicollinearity Test}

Multicollinearity test is to test the existence of a relationship between independent variables, and the following are the characteristics that multicollinearity does not occur if Tolerance> 0.10 and VIF $<10.00$.

Figure Multicollinearity Test Results

\begin{tabular}{|c|c|c|c|}
\hline \multirow{2}{*}{ Region } & \multirow{2}{*}{ Variabel } & \multicolumn{2}{|c|}{ Collinearity Statistics } \\
\cline { 3 - 4 } & & Tolerance $(>0,10)$ & VIF $(<10,00)$ \\
\hline \multirow{2}{*}{ Tangerang City } & $\mathrm{X} 1$ &, 737 & 1,356 \\
\cline { 2 - 4 } & $\mathrm{X} 2$ &, 737 & 1,356 \\
\hline \multirow{2}{*}{ South Tangerang } & $\mathrm{X} 1$ &, 474 & 2,111 \\
\cline { 2 - 4 } & $\mathrm{X} 2$ &, 474 & 2,111 \\
\hline
\end{tabular}

(Source: Results by Questionnaire)

And based on the data obtained above, it can be concluded that there is no multicollinearity in the two regression equations formed.

A. Questionnaire Test Results

\section{FIRST HYPOTHESIS TEST: TANGERANG CITY AREA}

\begin{tabular}{|c|c|c|c|c|}
\hline \multicolumn{5}{|c|}{ Model Summary } \\
\hline Model & $\mathrm{R}$ & R Square & $\begin{array}{c}\text { Adjusted R } \\
\text { Square }\end{array}$ & $\begin{array}{c}\text { Std. Error of the } \\
\text { Estimate }\end{array}$ \\
\hline 1 & $.547^{a}$ & .299 & .286 & 4.519 \\
\hline
\end{tabular}

a. The level of correlation that occurs between the variables $\mathrm{X} 1, \mathrm{X} 2$ and $\mathrm{Y}$ is quite strong because the Rhitung value $=0.547$ and more than $50 \%$ even though it is still below the value 1. 
PRIMANOMICS : JURNAL EKONOMI DAN BISNIS - VOL. 19 NO. 1 (2021)

Versi Online Tersedia di : https://jurnal.ubd.ac.id/index.php/ds

| 1412-632X (Cetak) | 2614-6789 (Online) |

b. Variables X1 and X2 only affect $29.9 \%$ on Y in the Tangerang area.

Coefficients $^{a}$

\begin{tabular}{|l|r|r|r|r|r|r|r|}
\hline \multirow{2}{*}{ Model } & \multicolumn{2}{|c|}{$\begin{array}{c}\text { Unstandardized } \\
\text { Coefficients }\end{array}$} & $\begin{array}{c}\text { Standardized } \\
\text { Coefficients }\end{array}$ & \multirow{2}{*}{$\mathrm{t}$} & \multicolumn{2}{|c|}{ Sig. } & \multicolumn{3}{|c|}{ Collinearity Statistics } \\
\cline { 2 - 4 } \cline { 6 - 8 } & \multicolumn{1}{c|}{$\mathrm{B}$} & Std. Error & \multicolumn{1}{c|}{ Beta } & & & Tolerance & \multicolumn{1}{c|}{ VIF } \\
\hline (Constant) & 28.768 & 3.141 & & 9.158 & .000 & & \\
TPromosi & .365 & .070 & .500 & 5.184 & .000 & .737 & 1.356 \\
TGaya & .057 & .067 & .082 & .853 & .396 & .737 & 1.356 \\
\hline
\end{tabular}

a. Dependent Variable: Tdecision

c. Regional Multiple Linear Regression Analysis 1

Based on the results of the regression equation questionnaire that is formed:

$\mathrm{Y}=28,768+0,365 \mathrm{X} 1+0,057 \mathrm{X} 2$

From the results of the equations formed in table 4.5 , it can be concluded that the variables $\mathrm{X} 1$ and $\mathrm{X} 2$ have a positive effect on variable $\mathrm{Y}$.

\begin{tabular}{|rl|r|r|r|r|r|}
\hline \multicolumn{1}{|c|}{ Model $^{2}$} & Sum of Squares & \multicolumn{1}{c|}{$\mathrm{df}$} & Mean Square & \multicolumn{1}{c|}{$\mathrm{F}$} & \multicolumn{1}{c|}{ Sig. } \\
\hline \multirow{2}{*}{1} & Regression & 889.936 & 2 & 444.968 & 21.791 & $.000^{\mathrm{b}}$ \\
& Residual & 2082.826 & 102 & 20.420 & & \\
& Total & 2972.762 & 104 & & & \\
\hline
\end{tabular}
a. Dependent Variable: TDecision
b. Predictors: (Constant), TStyle, TPromotion

d. Table $\mathrm{F}$ test results

From the results of the questionnaire, it can be seen that the value of Fcount> Ftable, or 21.791> $3.09(\mathrm{~N} 1=2, \mathrm{~N} 2=102)$, it can be concluded that H1 is ACCEPTED or X1 and X2 AFFECT Y on Respondents in Tangerang City.

\section{SECOND HYPOTHESIS TEST: SOUTH TANGERANG}

\begin{tabular}{|l|r|r|r|r|}
\hline Model & $R$ & R Square & \multicolumn{1}{|l|}{$\begin{array}{l}\text { Adjusted } R \\
\text { Square }\end{array}$} & $\begin{array}{l}\text { Std. Error of the } \\
\text { Estimate }\end{array}$ \\
\hline 1 & $.493^{\mathrm{a}}$ & .243 & .216 & 5.717 \\
\hline
\end{tabular}

a. The level of correlation that occurs between the variables $\mathrm{X} 1, \mathrm{X} 2$ and $\mathrm{Y}$ is not too strong because the value of Rhitung $=0.493$ and is far below the value of 1 .

b. Variables X1 and X2 only affect $24.3 \%$ of Y on South Tangerang consumers.

\begin{tabular}{|l|c|c|c|c|c|}
\hline Model & $\begin{array}{c}\text { Coefficients } \\
\text { Unstandardized } \\
\text { Coefficients }\end{array}$ & $\begin{array}{c}\text { Standardized } \\
\text { Coefficients }\end{array}$ & $\mathrm{t}$ & Sig. & $\begin{array}{c}\text { Collinearity } \\
\text { Statistics }\end{array}$ \\
\hline
\end{tabular}




\begin{tabular}{|l|r|r|r|r|r|r|r|}
\hline & & Std. Error & Beta & & & Tolerance & VIF \\
\hline (Constant) & 27.524 & 4.563 & & 6.032 & .000 & & \\
TPromosi & .256 & .154 & .278 & 1.659 & .103 & .474 & 2.111 \\
TGaya & .206 & .137 & .252 & 1.507 & .137 & .474 & 2.111 \\
\hline
\end{tabular}

a. Dependent Variable: TDecision

a. Regional Multiple Linear Regression Analysis 2

Based on the results of the questionnaire in table 4:10 above are:

$\mathrm{Y}=27.524+0.256 \mathrm{X} 1+0.206 \mathrm{X} 2$

From the results of the equations formed in Table 4.5, it can be concluded that the variables $\mathrm{X} 1$ and $\mathrm{X} 2$ have a positive effect on variable $\mathrm{Y}$

ANOVA ${ }^{\mathrm{a}}$

\begin{tabular}{|rl|r|r|r|r|r|}
\hline \multicolumn{1}{|c|}{ Model } & Sum of Squares & df & Mean Square & F & Sig. \\
\hline & Regression & 596.962 & 2 & 298.481 & 9.132 & $.000^{\mathrm{b}}$ \\
1 & Residual & 1862.972 & 57 & 32.684 & & \\
& Total & 2459.933 & 59 & & & \\
\hline
\end{tabular}

a. Dependent Variable: TDecision

b. Predictors: (Constant), TStyle, TPromotion

b. Table F test results

From the results of the questionnaire, it can be seen that the value of Fcount> Ftable, or 9.132> $3.16(\mathrm{~N} 1=2, \mathrm{~N} 2=102)$, it can be concluded that H1 is ACCEPTED or X1 and X2 INFLUENCE Y on Respondents in South Tangerang Region.

\section{THE THIRD HYPOTHESIS TEST: DIFFERENCES BETWEEN TANGERANG CITY AND SOUTH SELATAN AREAS}

a) From the equation obtained, it can be seen that in Tangerang City the positive effect due to $\mathrm{X} 1$ is not too influential when compared to the variable $\mathrm{X} 2$.

b) Meanwhile, in south Tangerang, the positive influence of X1 is almost equal to that of $\mathrm{X} 2$

c) So it can be concluded that H1 is ACCEPTED or there is a difference between X1 and $\mathrm{X} 2$ against $\mathrm{Y}$ in the two areas studied.

\section{CONCLUSIONS AND SUGGESTIONS}

\section{A. Conclusion}

The research conclusions obtained based on the results of the questionnaire are Hypothesis 1 and Hypothesis 2 Proven (H1 Accepted) where X1 and X2 affect $\mathrm{Y}$, and Hypothesis 3 is also 
PRIMANOMICS : JURNAL EKONOMI DAN BISNIS - VOL. 19 NO. 1 (2021)

Versi Online Tersedia di : https://jurnal.ubd.ac.id/index.php/ds

| 1412-632X (Cetak) | 2614-6789 (Online) |

proven (H1 Accepted) because there are differences in the selection between $\mathrm{X} 1$ and $\mathrm{X} 2$ in the two regions.

\section{B. Suggestions}

It is hoped that this research can be continued again because X1 and X2 in the two areas studied only affect less than $30 \%$ of Y

\section{REFERENCE}

\section{BOOK}

Dyanasari \& Harwiki, Wiwiek. (2018). Perilaku Konsumen. Yogyakarta : Penerbit deeppublish

Julius, Yudi. N \& Limakrisna, Nandan. (2016). Manajemen Pemasaran (Model Kepuasan dan Loyalitas Pelanggan). Yogyakarta : Penerbit deeppublish

Rangkuti, Freddy. (2017) Riset Pemasaran. Jakarta : Penerbit PT Gramedia Pustaka Umum bekerjasama dengan Sekolah Tinggi Ekonomi IBII

Setiadi, Nugroho J. (2015). Perilaku Konsumen. Edisi Revisi. Jakarta : Penerbit Prenadamedia Group

Sumarwan, Ujang. (2017). Perilakau Konsumen : Teori dan Penerapannya dalam Pemasaran.Edisi Kedua. Bogor : Penerbit GHALIA Indonesia

Tjiptono, Fandy. (2019). Strategi Pemasaran : Prinsip \& Penerapan. Yogyakarta : Penerbit ANDI

Utami, Christina Widya. (2017). Manajemen Ritel : Strategi dan Implementasi Operasional Bisnis Ritel Modern di Indonesia. Jakarta : Penerbit Salemba Empat

\section{JOURNAL}

Kusnawan, Agus; Andy Andy; Eso Hermawan; Diana Silaswara.dan Tjong Sefung (2020). The Effect of Digital Payment to Millennial Consumer Purchase Dicisions. Penelitian Dosen pada Fakultas Bisnis Universitas Buddi Dharma Tangerang, [Internet] [diunduh pada tanggal 10 Juli 2020 pukul 13 : 58]. Tersedia pada : http://testmagzine.biz/index.php/testmagzine/article/view/1651/1491

Kusnawan, Agus; Silaswara, Diana; Andy, Andy dan Sefung, Tjong. 2019.Pengaruh Diskon pada Aplikasi e-wallet terhadap Pertumbuhan Minta Pembelian Implusif Konsumen Milenial di Wilayah Tangerang. Penelitian Dosen pada Fakultas Bisnis Universitas Buddi Dharma Tangerang, [Internet] [diunduh pada tanggal 09 September 2020 pukul 19 : 58]. Tersedia pada : https://e-jurnal.lppmunsera.org/index.php/SM/article/view/1861

Kuspriyono, Taat (2017). Pengaruh Promosi Online dan Kemasan Terhadap Keputusan Pembelian Kosmetik Merek Sariayu Martha Tilaar. Tugas Akhir pada Akademi Manajemen Ilmu Komputer Bina Sarana Informatika, [Internet] [diunduh pada tanggal 06 September 2020 pukul 20 : 08 ]. Tersedia https://ejournal.bsi.ac.id/ejurnal/index.php/perspektif/article/view/2231

Prastowo, Griffan Agus. 2018. Pengaruh implementasi promosi online terhadap keputusan pembelian pada PT. Mitra Pariwara Gramed Malang. Skripsi pada Program Studi Manajemen Fakultas Ekonomi Universitas Islam Negeri Maulana Malik Ibrahim Malang, [Internet] [diunduh pada tanggal 02 September 2020 pukul 14 : 38]. Tersedia pada : http://etheses.uinmalang.ac.id/13296/

\section{INTERNET}

https://kabar24.bisnis.com/read/20200622/19/1255744/update-covid-19-global-9.035.426-kasus-diseluruh-dunia-50-persen-sembuh (Accessed on June 232020 at 10:28 am)

https://id.wikipedia.org/wiki/Pandemi koronavirus di Indonesia (Accessed on June 2, 2020 at 21:39)

https://bnpb.go.id/berita/presiden-tetapkan-covid19-sebagai-bencana-nasional (Accessed on 22 June 2020 at 20:44) 
https://www.kompas.com/tren/read/2020/04/20/175146965/ini-daftar-20-wilayah-di-indonesia-yangtetapkan-psbb (Accessed on 22 June 2020 at 19:39)

https://bnpb.go.id/berita/presiden-tetapkan-covid19-sebagai-bencana-nasional (Accessed on 22 June 2020 at 20:44)

https://www.liputan6.com/news/read/4257400/4-pernyataan-jokowi-soal-ramadan-dan-larangan-mudik (Accessed on 22 June 2020 at 20:46)

https://www.kompas.com/tren/read/2020/03/30/105141365/update-5-wilayah-di-indonesia-yangberlakukan-karantina-terbatas-hingga?page=all\#page2 (Accessed on June 22, 2020 at 20:51)https://finansial.bisnis.com/read/20200324/90/1217502/cegah-corona-meluas-bi-akan-batasijam-operasional-bank (Accessed on 22 June 2020 at 21:02) 